\title{
ANALISIS DAMPAK PENERAPAN SISTEM ERP TERHADAP KINERJA PENGGUNA
}

\author{
Aries Wicaksono; Hery Harjono Mulyo; Ignatius Edward Riantono \\ Accounting and Finance Department, Faculty of Economic and Communication, BINUS University \\ Jln. K.H. Syahdan No. 9, Palmerah, Jakarta Barat 11480 \\ aries.0202@gmail.com; heryhm@binus.edu; iriantono@binus.edu
}

\begin{abstract}
The background of this research was to determine how the impact of the implementation and use of ERP systems on user performance and the factors that affect the successful implementation of the ERP system so that it can have a positive impact for users of the ERP system after the implementation of ERP systems. This study aims to Knowing whether the implementation of ERP systems on firm performance impact on ERP users in the company and Produce conclusions in the form of an evaluation of the implementation of ERP in the company in order to provide a positive impact on user performance. The model used to evaluate the impact of the implementation of the ERP system is Quantity of Work, Quality of Work, Job Knowledge, Creativeness Cooperation, Dependability, Initiative, personal qualities. The method used in this research is descriptive qualitative method of analytical and evaluative, by analyzing the impact of the implementation of the ERP system to the components of the user's performance. The results obtained are implementing ERP systems have a positive impact on user performance components.
\end{abstract}

Keywords: Analysis, ERP System, User Performance

\begin{abstract}
ABSTRAK
Latar belakang penelitian ini adalah untuk mengetahui bagaimana dampak dari penerapan dan penggunaan sistem ERP terhadap kinerja pengguna dan faktor-faktor apa yang mempengaruhi suksesnya penerapan sistem ERP sehingga dapat memberikan dampak positif bagi pengguna sistem ERP setelah diterapkan sistem ERP. Penelitian ini bertujuan untuk Mengetahui apakah penerapan sistem ERP pada perusahaan memberikan dampak pada kinerja pengguna ERP dalam perusahaan dan Menghasilkan kesimpulan berupa evaluasi terhadap penerapan ERP dalam perusahaan agar memberikan dampak yang positif bagi kinerja pengguna.Model yang dipakai untuk mengevaluasi dampak penerapan sistem ERP adalah Quantity of Work, Quality of Work, Job Knowledge, Creativeness Cooperation,Dependability, Initiative,personal qualities. Metode yang digunakan dalam penelitian ini adalah metode kualitatif bersifat deskriptif analitis dan evaluatif, dengan menganalisis dampak dari penerapan sistem ERP terhadap komponen kinerja pengguna. Hasil yang diperoleh adalah penerapan sistem ERP berdampak positif terhadap komponen kinerja pengguna.
\end{abstract}

Kata kunci: Analisis, Sistem ERP, Kinerja Pengguna 


\section{PENDAHULUAN}

\section{Latar Belakang}

Di era ekonomi global yang sangat kompetitif dan cepat berubah, perusahaan dituntut menggunakan teknologi informasi untuk mendukung proses bisnisnya. Manajemen teknologi informasi membutuhkan visi strategi yang menyatukan antara teknologi informasi dan proses bisnis. Strategi teknologi informasi mengacu pada investasi spesifik dalam bentuk perbedaan jenis sistem, seperti sistem Enterprise Resource Planning (ERP). ERP (Enterprise Resource Planning) atau dalam bahasa Indonesia sering disebut dengan Perencanaan Sumber Daya Perusahaan adalah struktur sistem informasi yang dapat mengintegrasikan fungsi pemasaran (marketing), fungsi produksi, fungsi logistik, fungsi keuangan/finance, fungsi sumber daya, fungsi produksi, dan fungsi lainnya. ERP telah berkembang sebagai alat integrasi yang memiliki tujuan untuk mengintegrasikan semua aplikasi perusahaan ke pusat penyimpanan data sehingga dapat dengan mudah diakses oleh semua bagian yang membutuhkan, termasuk mengintegrasikan hubungan perusahaan dengan pemasok.

Integrasi data pada teknologi ERP dilakukan dengan single data entry, yaitu sebuah departemen fungsi yang memasukkan data, sehingga data ini dapat digunakan oleh fungsi-fungsi lainnya dalam perusahaan. Enterprise Resource Planning (ERP) merupakan suatu cara untuk mengelola sumber daya perusahaan dengan menggunakan teknologi informasi. Penggunaan ERP yang dilengkapi dengan hardware dan software untuk mengkoordinasi dan mengintegrasikan data informasi pada setiap area business processes untuk menghasilkan pengambilan keputusan yang cepat karena menyediakan analisa dan laporan keuangan yang cepat, laporan penjualan yang on time, laporan produksi dan persediaan. Program ERP sangat membantu perusahaan yang memiliki bisnis proses yang luas, dengan menggunakan database dan reporting tools manajemen yang terbagi. Business processes merupakan sekelompok aktivitas yang memerlukan satu jenis atau lebih input yang akan menghasilkan sebuah output dimana output ini merupakan value untuk konsumen. Software ERP mendukung pengoperasian yang efisien dari business processes dengan cara mengintegrasikan aktivitas-aktivitas dari keseluruhan bisnis termasuk sales, marketing, manufacturing, logistic, accounting, dan staffing.

Dalam sepuluh tahun terakhir, sistem ERP telah menjadi populer pada perusahaan-perusahaan besar di dunia, termasuk di Indonesia. Di samping perusahaan besar, perusahaan menengah dan kecil juga mulai mengadopsi sistem ERP. Sistem ERP mencerminkan strategis bisnis inovatif karena dapat meningkatkan efisiensi dan efektivitas perusahaan. Efisiensi dan efektivitas yang dihasilkan sistem ini mengubah peran akuntansi manajemen dengan menyediakan akses yang mudah dan cepat untuk data operasional yang dibutuhkan dalam pengambilan keputusan dan pengendalian manajemen perusahaan.

Teknologi ERP ini merupakan suatu solusi yang paling ideal bagi setiap perusahaan yang telah berkembang dengan pesat dan memiliki banyak keunggulan yang dapat membantu lebih meningkatkan performa perusahaan. Namun efektivitas pengaplikasian ERP ini berbeda dari satu perusahaan dengan perusahaan lainnya. Beberapa kesalahan yang tanpa disadari dilakukan oleh pihak perusahaan akan mengurangi efektivitas dari ERP sehingga dapat juga menyebabkan terjadinya kerugian pada perusahaan.

Kerugian yang dialami perusahaan dalam hal ini adalah operasional perusahaan yang terganggu secara langsung sehingga mengganggu kinerja pekerja dalam perusahaan yang menggunakan ERP. Kinerja pengguna ERP tersebut mempengaruhi performa perusahaan secara keseluruhan. Oleh karena itu, berdasarkan tujuan dari penerapan ERP seharusnya kinerja pengguna yang menggunakan ERP menjadi lebih produktif dan berkualitas dengan efektifnya ERP yang ada dalam perusahaan. 
Menjadi menarik melihat bagaimana dampak penerapan ERP yang telah diterapkan perusahaan terhadap kinerja pengguna ERP dilihat dari sisi pengguna sebagai pekerja dalam perusahaan dibandingkan dengan sebelum implementasi ERP atau sebelum menggunakan ERP . Untuk itu penelitian ini mengambil judul Analisis Dampak penerapan ERP terhadap Kinerja Pengguna. Dari tema atau judul tersebut diharapkan dapat memberikan gambaran mengenai faktorfaktor apa saja dari efektifitas ERP yang menunjang kinerja penggguna, sehingga dalam penerapan selanjutnya dapat menjadi pertimbangan bagi pengembang ERP dan pengguna ERP tersebut.

Dampak dari penerapan ERP seharusnya memberikan dampak positif bagi kinerja pengguna dalam hal ini pekerja dalam perusahaan. Faktor-faktor yang menjadi ukuran untuk menilai kinerja pengguna ERP dalam hal ini antara lain kualitas kerja (Quality of work), Kuantitas Kerja (quantity of work), Pengetahuan Kerja (job knowledge), Kreatifitas (Creativeness), Ketergantungan (dependability), Inisiatif (initiative), dan Kualitas Personal (personal qualities). Bagaimana dampak penerapan ERP terhadap kinerja pengguna ERP dan apa saja komponen-komponen dari kinerja pengguna yang meningkat, tetap atau menurun sebagai dampak dari penerapan ERP?

Penelitian ini mempunyai beberapa tujuan, adapun tujuan tersebut antara lain adalah untuk mengetahui apakah penerapan sistem ERP pada perusahaan memberikan dampak pada kinerja pengguna ERP dalam perusahaan. Selain itu, penelitian ini juga bertujuan untuk menghasilkan kesimpulan berupa evaluasi terhadap penerapan ERP dalam perusahaan agar memberikan dampak yang positif bagi kinerja pengguna. Manfaat dari penelitian ini, bagi peneliti adalah untuk dapat memperoleh gambaran utuh dampak penerapan ERP terhadap kinerja pengguna dalam perusahaan dan bagi pembaca adalah sebagai sarana yang bersifat informatif serta menjadi pengembangan pihak lain untuk melakukan penelitian yang lebih lanjut

\section{Tinjauan Pustaka}

Sistem informasi menurut Hall (2011) didefinisikan,"The information system is the set of formal procedures by which data are collected, processed into information and distributed to users." Dengan demikian dapat diartikan "Sistem informasi adalah kesatuan dari prosedur formal dengan data yang dikumpulkan, diproses menjadi informasi dan didistribusikan kepada user.

Konsep ERP menurut Yasin (2013), ERP (Enterprise Resource Planning) berasal dari MRP (Manufacture Resource Planning) dan CIM (Computer Integrated Manufacturing) yang diperkenalkan oleh perusahaan riset dan analisis Gartner, di mana sistem ERP mencoba untuk mencakup seluruh fungsi dasar yang dimiliki oleh suatu perusahaan baik perusahaan tersebut bergerak dibidang bisnis atau nirlaba. ERP ini merupakan suatu sistem di mana pada bagian dalam terdapat perangkat lunak yang memiliki fungsi yang saling berkaitan dan bersifat lebih memudahkan pengguna karena adanya standarisasi yang hanya menggunakan satu sistem yang terintegrasi dalam suatu perusahaan dan adanya satu database yang sama untuk penyimpanan data utama.

Sedangkan konsep ERP menurut Suryalena (2013), sistem ERP merupakan sebuah sistem informasi perusahaan yang dirancang untuk mengkoordinasikan seluruh sumber daya, informasi dan aktivitas yang diperlukan untuk proses bisnis lengkap. Sistem ini memiliki satu database dan software untuk mengolah datanya. Software tersebut memiliki fungsi untuk mengintegrasikan semua departemen dalam mengelola sumber daya perusahaan. Konsep dari ERP tersebut dapat diilustrasikan sebagai berikut; 


\section{KONSEP DASAR ERP}

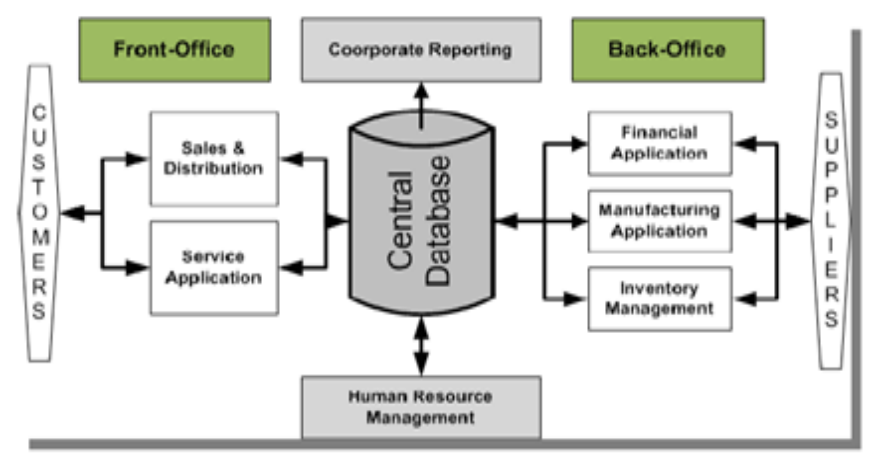

Gambar 1 Konsep Dasar ERP

Tujuann merupakan hal terpenting dari penerapan suatu sistem, menurut Yasin (2013), tujuan utama dari penerapan sistem ERP ini adalah untuk meningkatkan dan memperkuat efektivitas dari sumber daya yang ada dalam perusahaan, seperti; (1) Sumber daya manusia, di mana setiap anggota perusahaan memiliki tanggung jawab dan memiliki kemampuan untuk menciptakan suasana produktif dalam perusahaan. (2) Sumber daya produksi, agar perusahaan tersebut dapat menghasilkan produk yang lebih berkualitas. (3) Penjualan, di mana perusahaan mampu meningkatkan penjualan dengan adanya pemasaran yang lebih efektif. (4) Laporan keuangan perusahaan dan akuntansi logistik perusahaan yang lebih efektif dan terintegrasi. (5) Mampu bersaing dengan perusahaan kompetitor. (6) Untuk menghindari permasalahan sumber daya yang rumit di masa yang akan datang.

Konsep atau pengertian kinerja menurut Kurniawan, Lubis, dan Adam (2012), kinerja merupakan tingkat keberhasilan karyawan atas apa yang menjadi tanggung jawabnya dalam mencapai suatu tujuan perusahaan. Faktor-faktor yang mempengaruhi kinerja antara lain motivasi, kemampuan, pendidikan, pengetahuan, pengalaman, keahlian, pelatihan, minat, sikap, kepribadian, kondisi fisik dan berbagai jenis kebutuhan manusia lainnya baik biologis, sosial dan egoistik.

Sedangkan konsep atau pengertian menurut Murti dan Srimulyani (2013), kinerja adalah hasil atas apa yang dilakukan karyawan, seberapa banyak kontribusi karyawan tersebut terhadap perusahaan dan kemampuan karyawan tersebut dalam menyelesaikan seluruh tugas dan tanggung jawabnya. Faktor-faktor yang mempengaruhi kinerja pegawai adalah kemampuan dan motivasi. Kemampuan terdiri dari IQ dan knowledge, sedangkan motivasi terbentuk saat karyawan menghadapi situasi kerja berupa sesuatu yang menggerakkan karyawan tersebut agar mencapai tujuan perusahaan.

Konsep penilaian kinerja menurut Sujadi dan Setiyanti (2012), penilaian kinerja juga dapat dibagi menjadi beberapa dimensi yang saling berkaitan, antara lain; (1) Quantity of work, yaitu jumlah pekerjaan yang diselesaikan dalam suatu periode yang telah ditentukan. (2) Quality of work, yaitu kualitas pekerjaan sesuai dengan standar yang telah ditentukan. (3) Job knowledge, yaitu pengetahuan mengenai pekerjaan dan hal-hal apa saja yang menjadi tanggung jawabnya. (4) Creativeness, yaitu kreativitas untuk menciptakan solusi atas masalah-masalah yang timbul dalam pekerjaan. (5) Cooperation, yaitu kemampuan untuk bekerja sama dengan orang lain. (6) Dependability, yaitu kesadaran atas suatu penyelesaian pekerjaan yang harus dilakukan. (7) Initiative, yaitu kesadaran dan kemauan untuk memperluas tanggung jawab dalam pekerjaan. (8) Personal qualities, yaitu kualitas seorang pekerja yang meliputi kepribadian, kepemimpinan, sikap dalam keseharian dan integritasnya. 
Rangkuman kajian teoritik yang telah dianalisis dapat dilihat dalam tabel sebagai berikut :

Tabel 1 Rangkuman Kajian Teoritik

\begin{tabular}{|c|c|c|c|}
\hline No & Sumber Teori & Penjelasan & Hubungan Penelitian \\
\hline 1 & Yasin (2013) & $\begin{array}{l}\text { ERP merupakan suatu sistem dimana terdapat } \\
\text { didalamnya perangkat lunak yang memiliki } \\
\text { fungsi yang saling berkaitan dan bersifat lebih } \\
\text { memudahkan pengguna karena adanya } \\
\text { standarisasi dimana hanya menggunakan satu } \\
\text { sistem yang terintegrasi dalam suatu perusahaan } \\
\text { dan adanya satu database yang sama untuk } \\
\text { penyimpanan data utama. }\end{array}$ & $\begin{array}{l}\text { Sebagai dasar penentuan } \\
\text { sistem informasi yang } \\
\text { berbentuk ERP }\end{array}$ \\
\hline 2 & Suryalena (2009) & $\begin{array}{l}\text { Sistem ERP merupakan sebuah sistem informasi } \\
\text { perusahaan yang dirancang untuk } \\
\text { mengkoordinasikan seluruh sumber daya, } \\
\text { informasi dan aktifitas yang diperlukan untuk } \\
\text { proses bisnis lengkap. Sistem ini memiliki satu } \\
\text { database dan software untuk mengolah datanya. } \\
\text { Software tersebut memiliki fungsi untuk } \\
\text { mengintegrasikan semua departemen dalam } \\
\text { mengelola sumber daya perusahaan.menjamin } \\
\text { integritas data yang memadai }\end{array}$ & $\begin{array}{l}\text { Sebagai dasar penentuan } \\
\text { sistem informasi yang } \\
\text { berbentuk ERP }\end{array}$ \\
\hline 3 & Yasin (2013) & $\begin{array}{l}\text { Tujuan utama dari penerapan sistem ERP ini } \\
\text { adalah untuk meningkatkan dan memperkuat } \\
\text { efektivitas dari sumber daya yang ada dalam } \\
\text { perusahaan. }\end{array}$ & $\begin{array}{l}\text { Mengetahui tujuan dasar } \\
\text { dari penerapan ERP }\end{array}$ \\
\hline 4 & $\begin{array}{l}\text { Kurniawan, Lubis, dan Adam } \\
\text { (2012) }\end{array}$ & $\begin{array}{l}\text { Kinerja merupakan tingkat keberhasilan } \\
\text { karyawan atas apa yang menjadi tanggung } \\
\text { jawabnya dalam mencapai suatu tujuan } \\
\text { perusahaan. Faktor-faktor yang mempengaruhi } \\
\text { kinerja antara lain motivasi, kemampuan, } \\
\text { pendidikan, pengetahuan, pengalaman, keahlian, } \\
\text { pelatihan, minat, sikap, kepribadian, kondisi fisik } \\
\text { dan berbagai jenis kebutuhan manusia lainnya } \\
\text { baik biologis, sosial dan egoistik. }\end{array}$ & $\begin{array}{l}\text { Sebagai dasar menentukan } \\
\text { konsep kinerja pengguna }\end{array}$ \\
\hline 5 & Murti dan Srimulyani (2013) & $\begin{array}{l}\text { Kinerja adalah hasil atas apa yang dilakukan } \\
\text { karyawan, seberapa banyak kontribusi karyawan } \\
\text { tersebut terhadap perusahaan dan kemampuan } \\
\text { karyawan tersebut dalam menyelesaikan seluruh } \\
\text { tugas dan tanggung jawabnya. Faktor-faktor } \\
\text { yang mempengaruhi kinerja pegawai adalah } \\
\text { kemampuan dan motivasi. Kemampuan terdiri } \\
\text { dari IQ dan knowledge, sedangkan motivasi } \\
\text { terbentuk saat karyawan menghadapi situasi } \\
\text { kerja berupa sesuatu yang menggerakkan } \\
\text { karyawan tersebut agar mencapai tujuan } \\
\text { perusahaan. }\end{array}$ & $\begin{array}{l}\text { Sebagai dasar menentukan } \\
\text { konsep kinerja pengguna }\end{array}$ \\
\hline 6 & Sujadi dan Setiyanti (2012) & $\begin{array}{l}\text { Penilaian kinerja juga dapat dibagi menjadi } \\
\text { beberapa dimensi yang saling berkaitan, antara } \\
\text { lain Quality of Work,Quality Of Work,Job } \\
\text { Knowledge, Creativeness, Cooperation, } \\
\text { Dependability, Iniative, Personal Qualities. }\end{array}$ & $\begin{array}{l}\text { Sebagai dasar analisis } \\
\text { komponen kinerja } \\
\text { pengguna }\end{array}$ \\
\hline
\end{tabular}




\section{METODE}

Berdasarkan ruang lingkup penelitian yang akan dikaji, maka jenis penelitian ini adalah penelitian lapangan (field research) yang dikaji dengan kajian evaluatif. Penelitian ini menggunakan pendekatan kualitatif,. Penelitian kualitatif untuk menjawab permasalahan terkait ada tidaknya dampak dari penerapan ERP terhadap kinerja pengguna. Lokasi penelitian di Jakarta dan Bekasi. Kemudian sumber data atas penelitian ini adalah data primer. Data primer adalah data-data lapangan yang diperoleh dari wawancara,survei dan observasi langsung kepada sumber data. Teknik pengumpulan data yang dilakukan adalah dengan menggunakan wawancara yaitu dengan melakukan wawancara secara terbuka dan mendalam kepada pengguna sistem ERP yang merasakan pengalaman sebelum menggunakan ERP dan setelah menggunakan ERP. Survei dilakukan ke 3 Perusahaan yang menggunakan sistem ERP.

\section{HASIL DAN PEMBAHASAN}

\section{Analisis Kinerja Pengguna Sebelum dan Sesudah Penerapan Sistem ERP}

Perlu digarisbawahi, bahwa tujuan utama dalam penerapan ERP adalah untuk meningkatkan dan memperkuat efektivitas dari sumber daya yang ada dalam perusahaan, sumber daya yang dibahas dalam penelitian ini adalah sumber daya manusia yang menggunakan sistem ERP. Salah satu kriteria sukses penerapan ERP adalah kinerja operasional perusahaan yang meningkat, di mana kinerja perusahaan ditopang atau didukung oleh kinerja pekerja atau pegawainya.

Berdasarkan penjelasan diatas dapat dibuat perbandingan terkait delapan kriteria dari penilaian kinerja terkait sebelum penerapan dan sesudah penerapan ERP yang dilakukan perusahaan, delapan kriteria penilaian kinerja yaitu Quantity of Work (jumlah pekerjaan yang diselesaikan dalam satu periode tertentu), Quality of Work (kualitas pekerjaan sesuai dengan standar yang telah ditentukan), Job Knowledge (pengetahuan mengenai pekerjaan dan hal-hal apa saja yang menjadi tanggung jawabnya), Creativeness (kreativitas untuk menciptakan solusi atas masalah-masalah yang timbul dalam pekerjaan),Cooperation (kemampuan untuk bekerja sama dengan orang lain), Dependability (kesadaran atas suatu penyelesaian pekerjaan yang harus dilakukan), Initiative (kesadaran dan kemauan untuk memperluas tanggung jawab dalam pekerjaan), personal qualities (kualitas seorang pekerja yang meliputi kepribadian, kepemimpinan, sikap dalam keseharian dan integritasnya).

Berdasarkan data dan informasi yang diperoleh di lapangan untuk komponen quantity of work (jumlah pekerjaan yang diselesaikan dalam satu periode tertentu). Kuantitas pekerjaan yang dihasilkan sebelum dilakukan penerapan dan dibandingkan dengan setelah penerapan ERP, dari 25 informan yang memberikan informasi terkait peningkatan kuantitas pekerjaan terkait penerapan ERP secara keseluruhan mereka menyatakan bahwa output kuantitas pekerjaan yang mereka hasilkan lebih banyak dibandingkan dengan sebelum menggunakan ERP. Ada beberapa penyebab yang dapat diambil dari peryataan informan antara lain dengan adanya ERP sebagian informan dapat melakukan pekerjaan lebih fokus bekerja, sesuai dengan job description informan sehingga dapat menghasilkan atau menyelesaikan lebih banyak pekerjaan dibandingkan sebelum menggunakan ERP, sebelum menggunakan ERP sebagian informan merasa tidak fokus dalam menyelesaikan pekerjaan yang seharusnya mereka kerjakan karena menerima pekerjaan yang bukan pekerjaan para informan, pernyataan yang kedua yaitu dengan adanya ERP sebagian informan dapat mengelola dan memantau pekerjaan yang telah mereka selesaikan dengan lebih cepat dan efisien, sehingga sebagian informan dapat mengelola waktu untuk menyelesaikan pekerjaan mereka sesuai dengan target yang telah ditentukan. Sebelum menggunakan ERP dibutuhkan waktu untuk memantau dan mengecek pekerjaan yang telah diselesaikan oleh para informan. 
Untuk komponen quality of work (kualitas pekerjaan sesuai dengan standar yang telah ditentukan), semua informan yaitu 25 informan yang memberikan data dan informasi menyatakan dampak positif dengan adanya penerapan sistem ERP adalah semua pekerjaan yang dilakukan dan dikerjakan oleh informan menjadi terstandardisasi, karena pada saat tahap implementasi semua proses bisnis yang masih bersifat manual dibuat ke dalam sistem yang terkomputerisasi dalam bentuk sistem ERP. Standar kualitas yang dimaksud dalam hal ini adalah standar hasil pekerjaan dan standar waktu penyelesaian pekerjaan. Sebelum adanya penerapan sistem ERP walaupun standar pekerjaan sudah ditetapkan dalam standar operasional perusahaan, tetapi dalam melaksakannya sering terjadi penyesuaian-penyesuaian akibat perubahan kondisi di lapangan sehingga tidak jelas seberapa jauh standar yang ada bisa diubah menyesuaikan dengan kondisi di lapangan. Dengan digunakannya sistem ERP semua perubahan dari standar dapat ditentukan tingkat toleransi dari perubahan tersebut.

Kemudian untuk komponen Job knowledge (pengetahuan mengenai pekerjaan dan hal-hal apa saja yang menjadi tanggung jawabnya) semua informan yaitu 25 informan yang memberikan data dan informasi menyatakan sebelum adanya sistem ERP untuk mengetahui tanggung jawab dan pengetahuan mengenai pekerjaan mereka, sebagian informan harus mengkonfirmasi ke bagian Human Resource Department (HRD) atau bagian SDM untuk mengetahui pekerjaan mereka dan apa yang menjadi tanggung jawab informan. Sebagian informan harus membaca standar operasional perusahaan secara detail jika ada sengketa terkait wewenang dan tanggung jawab terhadap suatu pekerjaan. Sehingga seringkali terjadi konflik akibat tidak semua pekerja mengetahui tanggung jawab dan pengetahuan mengenai pekerjaan yang seharusnya mereka laksanakan. Di dalam sistem ERP semua yang terkait dengan pekerjaan yang harus dikerjakan dan dilaksanakan oleh masing-masing pengguna telah distandardisasi dalam modul dan menu yang disesuaikan dengan fungsi dan jabatan masingmasing pengguna. Selain itu bagaimana cara pelaksanaan serta ukuran penyelesaian pekerjaan juga ada dalam modul masing-masing pengguna sistem ERP sesuai dengan fungsi dan jabatan pengguna.

Terkait dengan komponen Creativeness (kreativitas untuk menciptakan solusi atas masalahmasalah yang timbul dalam pekerjaan), salah satu keunggulan dari sistem ERP adalah pengolahan data menjadi informasi dengan lebih cepat dan efisien, selain itu untuk menganalisis suatu permasalahan dengan menggunakan data dan informasi dari ERP jauh lebih cepat. Semua informan yaitu 25 informan yang memberikan testimoni dan pernyataan menyatakan bahwa sebelum adanya penerapan sistem ERP proses analisis menggunakan data dan informasi untuk menyelesaikan suatu permasalahan butuh waktu yang tidak singkat, dikarenakan proses mengubah data menjadi informasi jika dilakukan secara manual butuh waktu yang tidak singkat sehingga berpengaruh terhadap penyelesaian suatu masalah atau proses pengambilan keputusan. Setelah adanya penerapan sistem ERP dan penggunaan sistem ERP para informan menyatakan terbantu untuk membuat penyelesaian suatu masalah atau pengambilan keputusan sehingga solusi dan keputusan menjadi lebih kreatif, kreatif di sini diartikan sebagai solusi dan keputusan yang di luar keputusan dan solusi yang normatif dimana keputusan dan solusi kreatif tersebut dapat dijalankan dengan efisien dan efektif.

Komponen Cooperation (kemampuan untuk bekerja sama dengan orang lain), berdasarkan testimoni dan pernyataan dari informan, sebagian informan menyatakan bahwa dengan adanya sistem ERP sistem bekerja mereka menjadi lebih individual, karena semua pekerjaan mereka menjadi terstandardisasi. Sebagian informan yang lain menyatakan mereka dapat meningkatkan kerjasama dalam dalam internal divisi maupun antar divisi karena komunikasi dapat dilakukan dengan efisien dan efektif di dalam sistem ERP. Setelah dianalisis informan yang menyatakan bahwa mereka bekerja menjadi lebih individualis ternyata tidak memanfaatkan fitur atau fasilitas komunikasi yang sudah tertanam atau ada pada sistem ERP. Salah satu fungsi untuk mengefektifkan komunikasi antar fungsi dan unit serta antarpersonal dalam satu perusahaan yang menggunakan ERP adalah fungsi komunikasi yang bisa berupa chat, pesan singkat dan forum diskusi terkait penyelesaian pekerjaan.

Kemudian untuk komponen dependability (kesadaran atas suatu penyelesaian pekerjaan yang harus dilakukan) Semua informan yaitu 25 informan yang memberikan testimoni dan pernyataan 
menyatakan bahwa sebelum adanya penerapan sistem ERP ketergantungan penyelesaian kerja mereka masih sangat tergantung dengan unit dan fungsi lain karena data dan informasi yang dibutuhkan untuk penyelesaian kerja mereka diolah secara manual oleh fungsi lain dalam perusahaan. Setelah adanya penggunaan dan penerapan sistem ERP, semua informan menyatakan bahwa dengan meningkatnya proses pengolahan data menjadi informasi serta peningkatan arus data antar fungsi atau unit memberikan dampak positif kepada informan dengan meningkatnya tingkat penyelesaian pekerjaan para informan atas data yang mereka butuhkan untuk penyelesaian pekerjaan mereka.

Untuk komponen inititive (kesadaran dan kemauan untuk memperluas tanggung jawab dalam pekerjaan), sebagian informan menyatakan sebelum menggunakan sistem ERP merasakan mempunyai inisiatif yang lebih dibandingkan dibandingkan dengan setelah menggunakan sistem ERP, karena masalah yang ditemui membuat sebagian informan tersebut mempunyai inisiatif dalam menyelesaikannya. Setelah menggunakan sistem ERP atau setelah diimplementasikannya sistem ERP mereka menyatakan kurang mempunyai inisiatif karena semua pekerjaannya sudah ada dalam sistem ERP yang digunakan. Sedangkan sebagian dari informan menyatakan bahwa dengan diterapkannya sistem ERP atau digunakannya sistem ERP mereka dapat menyelesaikan pekerjaannya dengan lebih cepat dan dapat melakukan inisiatif pekerjaan yang lain yang masih berkaitan dengan fungsi dan tanggung jawab mereka. Sebelum menggunakan sistem ERP mereka merasa kurang dapat berinisiatif karena sibuk menyelesaikan pekerjaannya.

Kemudian untuk komponen personal qualities (kualitas seorang pekerja yang meliputi kepribadian, kepemimpinan, sikap dalam keseharian dan integritasnya) semua informan menyatakan bahwa dengan diterapkannya sistem ERP semua pengguna menjadi lebih disiplin dan mengikuti aturan yang telah ditetapkan perusahaan yaitu standar operasional prosedur. Standar operasional prosedur tersebut ada dalam penggunaan sistem ERP.Selain itu para informan pengguna sistem ERP menyatakan dibandingkan sebelum menggunakan sistem ERP mereka menyatakan bisa menjaga integritas mereka karena semua pekerjaan yang dikerjakan terpantau melalui sistem ERP.

\section{Evaluasi Dampak Penerapan ERP terhadap Kinerja Pengguna}

Berdasarkan pembahasan di atas dapat dianalisis secara umum penerapan ERP memberikan dampak yang positif bagi kinerja pengguna. Untuk komponen quantity of work (jumlah pekerjaan yang diselesaikan dalam satu periode tertentu), penerapan sistem ERP memberikan dampak yang positif karena informan menghasilkan kuantitas pekerjaan yang lebih banyak dalam satu periode. Serta dapat memantau pekerjaan yang telah dan belum selesai dengan menggunakan sistem ERP dengan lebih cepat.

Kemudian komponen quality of work (kualitas pekerjaan sesuai dengan standar yang telah ditentukan), penerapan ERP memberikan dampak positif karena pekerjaan informan memiliki standar yang jelas dengan menggunakan sistem ERP, sehingga terkait standar pekerjaan memiliki standar yang jelas. Untuk komponen Job knowledge (pengetahuan mengenai pekerjaan dan hal-hal apa saja yang menjadi tanggung jawabnya), penerapan ERP memberikan dampak yang positif karena informasi pekerjaan, standar waktu penyelesaian dan tata cara penyelesaian pekerjaan semua informasinya dimasukkan ke dalam sistem ERP.

Komponen Creativeness (kreativitas untuk menciptakan solusi atas masalah-masalah yang timbul dalam pekerjaan), penerapan ERP memberikan dampak positif bagi informan, karena sistem ERP menyediakan informasi yang lebih lengkap dan cepat. Informasi tersebut berguna bagi informan dalam hal penyelesaian pekerjaan dan membuat keputusan-keputusan yang didasarkan atas informasi yang kualitasnya lebih baik dibandingkan dengan menggunakan proses yang manual, dimana informasi yang disediakan menjadi lebih terbatas dan membutuhkan proses yang tidak cepat dan efisien.Kemudian untuk komponen Cooperation (kemampuan untuk bekerja sama dengan orang lain), 
penerapan ERP disimpulkan oleh sebagian informan mempunyai dampak positif karena dapat berinteraksi menggunakan sistem ERP, fitur ERP yang diterapkan dalam perusahaan telah mendukung komunikasi antar fungsi dan unit dalam perusahaan melalui sistem ERP. Sedangkan sebagian informan memberikan pernyataan bahwa sistem ERP memberikan dampak yang negatif terkait kerjasama, karena semua pekerjaan mereka dikelola di sistem ERP dan menghilangkan hubungan dengan fungsi dan unit lain. Dari hasil observasi dan wawancara lebih lanjut ternyata informan tersebut belum memanfaatkan fitur komunikasi yang ada pada sistem ERP. Dalam hal ini sosialisasi atas semua fungsi sistem ERP menjadi sangat penting karena pengguna dapat memaksimalkan semua fungsi yang terkait dengan bidang pekerjaannya.

Kemudian komponen dependability (kesadaran atas suatu penyelesaian pekerjaan yang harus dilakukan), penerapan sistem ERP memberikan dampak yang positif bagi para pengguna sistem ERP, karena meningkatnya tingkat penyelesaian kerja sebagai dampak dari peningkatan proses bisnis dari segi kecepatan proses dan ketepatan proses sehingga pengguna sistem ERP mendapatkan data dan informasi yang dibutuhkan untuk menyelesaikan suatu pekerjaan menjadi lebih cepat. Komponen selanjutnya yaitu initiative (kesadaran dan kemauan untuk memperluas tanggung jawab dalam pekerjaan), penerapan sistem ERP memberikan dua dampak terhadap informan yaitu sebagian menyatakan mempunyai inisiatif yang lebih dan sebagian menyatakan tidak mempunyai inisiatif. Informan yang menyatakan mempunyai inisiatif lebih dikarenakan mereka mempunyai waktu penyelesaian kerja yang lebih cepat sehingga dapat berinisiatif mengerjakan pekerjaan selanjutnya, kemudian informan yang menyatakan tidak mempunyai inisiatif karena semua pekerjaan telah dimasukkan ke dalam modul sistem ERP yang mereka gunakan, sehingga merasa tidak perlu inisiatif mengerjakan yang lain. Dari hasil analisis bahwa hal ini bukan merupakan suatu masalah jika semua pekerjaan yang seharusnya dikerjakan oleh pengguna telah terakomodasi di sistem ERP.

Komponen terakhir yaitu personal qualities (kualitas seorang pekerja yang meliputi kepribadian, kepemimpinan, sikap dalam keseharian dan integritasnya), setelah penerapan sistem ERP semua pengguna sistem ERP menyatakan memperoleh dampak positif terhadap kualitas personal pengguna dari segi kedisiplinan, koordinasi pekerjaan dalam satu unit atau divisi, kemudian integritas, dan yang juga penting informan memperoleh nilai lebih karena telah berpengalaman menggunakan sistem ERP.

\section{SIMPULAN}

Berdasarkan hasil evaluasi terkait dampak dari penerapan sistem ERP terhadap kinerja pengguna dari sistem ERP tersebut dapat disimpulkan bahwa secara umum sistem ERP memberikan dampak yang positf kepada kinerja pengguma. Berdasarkan data dan informasi penerapan ERP memberikan dampak positif pada komponen kinerja Quantity of Work (jumlah pekerjaan yang diselesaikan dalam satu periode tertentu), Quality of Work (kualitas pekerjaan sesuai dengan standar yang telah ditentukan), Job Knowledge (pengetahuan mengenai pekerjaan dan hal-hal apa saja yang menjadi tanggung jawabnya), Creativeness (kreativitas untuk menciptakan solusi atas masalahmasalah yang timbul dalam pekerjaan), Dependability (kesadaran atas suatu penyelesaian pekerjaan yang harus dilakukan), personal qualities (kualitas seorang pekerja yang meliputi kepribadian, kepemimpinan, sikap dalam keseharian dan integritasnya). Komponen diatas secara keseluruhan terdampak positif dengan adanya penggunaan sistem ERP pada perusahaan.

Kemudian untuk komponen Initiative (kesadaran dan kemauan untuk memperluas tanggung jawab dalam pekerjaan) dan komponen Cooperation (kemampuan untuk bekerja sama dengan orang lain), kedua komponen tersebut sebagian informan terdampak positif karena penerapan dan penggunaan sistem ERP dan sebagian informan tidak mendapatkan dampak positif bahkan berkurang 
karena penerapan dan penggunaan sistem ERP. Untuk komponen Initiative (kesadaran dan kemauan untuk memperluas tanggung jawab dalam pekerjaan), para informan yang menyatakan tidak mendapatkan dampak positif karena penggunaan dan penerapan ERP dapat disimpulkan tidak menjadi masalah selama semua pekerjaan mereka terakomodasi dalam sistem ERP yang diterapkan dan para informan telah menyelesaikan semua tanggung jawab pekerjaan mereka, karena para informan menganggap kurang berinisiatif karena semua pekerjaan mereka ada di sistem ERP yang terapkan. Untuk komponen Cooperation (kemampuan untuk bekerja sama dengan orang lain), para informan yang yang menyatakan tidak mendapatkan dampak positif karena penggunaan dan penerapan ERP dapat disimpulkan bahwa adanya kurang sosialisasi terhadap semua fitur dan fungsi sistem ERP yang dikembangkan pada perusahaan sehingga fitur komunikasi tidak diketahui oleh sebagian informan dan menjadi dasar bahwa mereka kurang bisa berkomunikasi dan berkoordinasi dengan fungsi dan unit lain dengan menggunakan sistem ERP.

Berdasarkan simpulan di atas, dalam penerapan suatu sistem ERP ada beberapa hal yang sangat penting yang menjadi kunci kesuksesan penerapan sistem ERP dan sebaiknya ditingkatkan baik oleh perusahaan maupun pengembang sistem ERP yaitu komitmen manajemen dan pelatihan penggunaan sistem ERP. Komitmen manajemen diperlukan agar sistem ERP yang telah dibangun dan diterapkan dalam perusahaan digunakan secara maksimal secara menyeluruh, sehingga fungsi sistem ERP dapat berjalan dengan semestinya. Kemudian faktor pelatihan menjadi penting karena pengguna mendapatkan informasi bagaimana menggunakan semua fungsi dalam sistem ERP yang ada secara maksimal, sehingga tujuan penerapan sistem ERP yaitu meningkatkan dan memperkuat efektivitas dari sumber daya yang ada dalam perusahaan.

\section{DAFTAR PUSTAKA}

Hall, J. R. (2011). IT Auditing. USA: South Western Cengage Learning.

Kurniawan, D., Lubis, A.R., Adam, M. (2012). Pengaruh Budaya Kerja Dan Motivasi Kerja Terhadap Kinerja Karyawan International Federation Red Cross (Ifrc) Banda Aceh. Jurnal Manajemen, 1(1), Pascasarjana Universitas Syiah Kuala.

Murti, H., Srimulyani, V. A. (2013). Pengaruh Motivasi Terhadap Kinerja Pegawai Dengan Variabel Pemediasi Kepuasaan Kerja Pada Pdam Kota Madiun. Jurnal Riset Manajemen dan Akuntansi, 1(1).

Sujadi, Setiyanti, S. W. (2012). Perancangan Penilaian Kinerja Pegawai Berdasarkan Kompetensi Spencer. Jurnal STIE Semarang, 4(1).

Suryalena. (2013). Enterprise Resource Planning (Erp) Sebagai Tulang Punggung Bisnis Masa Kini. Jurnal Aplikasi Bisnis, 3(2).

Yasin, V. (2013). Pentingnya Sistem Enterprise Resource Planning (Erp) Dalam Rangka Untuk Membangun Sumberdaya Pada Suatu Perusahaan. Jurnal Manajemen Informatika, 4(VI), Januari 2013. Sekolah Tinggi Manajemen Informatika dan Komputer Jayakarta. 